\title{
Investigating the effect of big five personality traits in Iranian EFL bilingual learners
}

\author{
Mojtaba Maghsoudi ${ }^{1}$, Fatemeh Samadi $^{2}$, Fatemeh Aziz Mohammadi ${ }^{3}$ \\ ${ }^{1}$ Farhangian University, Shahid Bahonar branch, Arak, Iran \\ ${ }^{2}$ Young Researchers and Elite Club, Arak Branch, Islamic Azad University, Arak Branch \\ ${ }^{3}$ Islamic Azad University, Arak branch, Iran \\ Email address: \\ maghsudim@yahoo.com (M. Maghsoudi), Fatemehsamadi36@yahoo.com (F. Samadi)
}

\section{To cite this article:}

Mojtaba Maghsoudi, Fatemeh Samadi, Fatemeh Aziz Mohammadi. Investigating the Effect of Big Five Personality Traits in Iranian EFL Bilingual Learners. International Journal of Language and Linguistics. Special Issue: Language Teaching and Learning Key Principles (LTLKP). Vol. 1, No. 4-1, 2013, pp. 26-32. doi: 10.11648/j.ijll.s.20130101.15

\begin{abstract}
The present study sought to find out whether big five personalities have any impact on Iranian EFL bilingual learners and if so, which type of personality can be more tangible on these learners. To meet the aims of this study, 93 male and female Iranian high school learners in 2 groups were asked to participate in this study. Subjects were asked to fill five big questionnaires. Statistical analysis based on Mean scores, standard deviation and Multivariate Analyses (MANOVA) revealed: 1-There was significant difference among two groups in five big personality.2- Female bilingual learners were more extrovert than male bilingual learners.
\end{abstract}

Keywords: Big Five, Bilingualism, Extroversion and Introversion

\section{Introduction}

\subsection{What is Personality}

As cherry (2013) has mentioned personality is made up the characteristic patterns of thoughts, feelings, and behaviors that make a person unique. It arises from within the individual and remains fairly consistent throughout life. He pointed out the theories of Personality that a number of different theories have emerged to explain different aspects of personality. Some theories focus on explaining how personality develops while others are concerned with individual differences in personality

\subsection{What Are the Big Five Dimensions of Personality}

First, the present researchers have mentioned five basic dimensions of personality which have proposed by personality researchers and often referred to as the "Big 5" personality traits.

As a matter of fact, evidence of research has been growing over the past 50 years, which started with the research of Fiske (1949) and then widespread by other researchers including Norman (1967), Goldberg (1981), and McCrae \& Costa (1987).
Gosling, Rentfrow and Swann (2003) discussed about the role big five personality traits that the Big-Five framework is a hierarchical model of personality traits with five broad factors, which represent personality at the broadest level of abstraction. Each bipolar factor (e.g., Extraversion vs. Introversion) summarizes several more specific facets (e.g., Sociability), which, in turn, subsume a large number of even more specific traits (e.g., talkative, outgoing). The Big-Five framework suggests that most individual differences in human personality can be classified into five broad, empirically derived domains.

Cherry (ibid) reviewed five categories which are usually described as follows:

1. Extraversion: This trait includes characteristics such as excitability, sociability, talkativeness, assertiveness and high amounts of emotional expressiveness.

2. Agreeableness: This personality dimension includes attributes such as trust, altruism $m_{2}$ kindness, affection, and other behaviors.

3. Conscientiousness: Common features of this dimension include high levels of thoughtfulness, with good impulse control and goal-directed behaviors. Those high in conscientiousness tend to be organized and mindful of details. 
4. Neuroticism: Individuals high in this trait tend to experience emotional instability, anxiety, moodiness, irritability, and sadness.

5. Openness: This trait features characteristics such as imagination and insight, and those high in this trait also tend to have a broad range of interests.

$\mathrm{He}$ noted that each of the five personality factors represents a range between two extremes. For example, extraversion represents a continuum between extreme extraversion and extreme introversion.

Komarraju , Steven, Ronald , Schmeck\& Avdic(2011) pointed out that the Big Five framework of personality traits (Costa \& McCrae, 1992) has emerged as a robust and parsimonious model for understanding the relationship between personality and various academic behaviors (Poropat, 2009).

In this part, some definitions of bilingualism have been expressed which proposed by different researchers.

\subsection{What is Bilingualism}

In one perspective, being bilingual equals being able to speak two languages perfectly, as Bloomfield in1935's defined bilingualism as 'the native-like control of two languages'. On the other hand, Macnamarain 1967's suggested that a bilingual is anyone who possesses a minimal competence in only one of the four language skills, listening comprehension, speaking, reading and writing, in a language other than his mother tongue.

As Maghsoudi(2010)has mentioned bilingualism is a difficult concept to define, since many theories vary with respect to how much exposure a person needs to become native in a language. There is no general agreement sufficiently to carry on a limited casual conversation, but we cannot set specific limits on proficiency or how much the speaker in question is speaking or demonstrating comprehension of another speaker.

Maghsoudi (ibid) discussed that defining bilingualism might at first seem self-evident: a bilingual person can speak more than one language. However, defining the term becomes more complicated when one starts to consider what knowing a language actually means and how one defines things such as fluency. Bilinguals' language proficiency may vary considerably from being able to communicate to some extent in a second language, to having considerable skills in both languages. Since the speakers' skills in a second language might vary from native-like competence to knowing only a few areas of research, there are different degrees of bilingualism.

So, some people are born bilingual, some aspire to bilingualism, and others have bilingualism thrust upon them later in life.

Regarding above discussion two hypotheses were formulated as follows.

\subsection{Research Hypotheses}

The present study set out to find answers to the following research questions:

H1: There is significant difference between male bilinguals and female bilinguals in big five personality traits.

H2: Female bilinguals are more extrovert than male bilinguals.

\section{Methodology}

\subsection{Participants}

The initial sample of this study consisted of 112 female and male students with the age range of 15-18. Through a background questionnaire some demographic information about subjects were elicited.

\subsection{Instruments}

The following instruments have been used in the current study:

\subsubsection{Background Questionnaire}

It was utilized to elicit some information as: the subjects' full name, their age, name of their school and the language/languages they use.

\subsubsection{General English Proficiency Test (Transparency Test)}

This test has been composed of multiple-choice cloze passage, vocabulary, grammar, and reading comprehension sections. In order to have a reliable test of proficiency at the piloting stage the test was given to 15 students, who were selected randomly, and its reliability was estimated through the K-R21 formula as .85 and then the test was found reliable for the purpose of this study.

The time allotted for taking this test was also determined at the piloting stage as 40 minutes. Duration of the test was estimated by calculating the time spent by the fastest and the slowest students in answering the test divided by 2 . Thus, the time allotted for the test was: $\frac{50+90}{2}=\mathbf{4 0}$

\subsubsection{Big five Questionnaire}

This test focused on big five personality traits. Additionally, it aimed to explore the differences in the participants' traits by their demographic information. The items were put in a 5-point Liker scale from Level 1: Strongly Disagree to Level 5: Strongly Agree.

\subsection{Procedure}

The following procedures were adopted in order to meet the objective of this study:

Phase1: The Background questionnaire was given to the subjects to fill them out.

Phase2: The Transparent test was given to 112 (PersianTurkish) male and female high school students who were bilinguals. Two groups of high and low language proficiency levels were identified, that is, those whose scores were 1SD below the mean were taken as Low and 
those whose scores were 1SD above the mean as high level, making 98 students in total. The time allowed as determined at the pilot study was 40 minutes.

Phase3: The big five questionnaire was give to all subjects to fill them out in 15 minutes.

\section{Results and Discussion}

In order to compare mean scores of all subjects, Multivariate analyses (MANOVA) has been used by researchers.

Table 1. Descriptive statistics of big five personality traits on male and female bilingual learners

\begin{tabular}{llllll}
\hline Group & Neuroticism & Openness & Extraversion & Agreeableness & Conscientiousness \\
\hline Male bilinguals mean & 20.04 & 20.84 & 21.04 & 22.04 & 22.48 \\
Male bilinguals SD & 5.06 & 5.52 & 4.13 & 6.25 & 6.18 \\
Female bilinguals mean & 19.46 & 21.76 & 22.84 & 24.54 & 24.64 \\
Female bilinguals SD & 6.40 & 6.36 & 5.75 & 7.19 & 6.23 \\
P value & 0.253 & 0.413 & 0.030 & 0.062 & 0.865 \\
DF & 1 & 1 & 1 & 1 & 1 \\
F & 1.32 & 0.675 & 4.86 & 3.55 & 0.029 \\
\hline
\end{tabular}

Statistical analyses indicated that there isn't meaningful difference between two groups in four personality traits (Neuroticism, Openness, Agreeableness, Conscientiousness), because $\mathrm{p}=0.253,0.413,0.062$, $0.865>0.05$.

So, regarding mean and standard deviation in four personality traits, the first hypothesis was rejected.

However, according to obtained data which is clear in table1, there is significant difference between male bilingual and female bilingual learners in Extroversion traits because $p=0.030<0.05$. In other word, female bilinguals are more extrovert than male bilinguals. So, the second hypothesis was accepted. The graph of statistical analyses is obvious in figure1,too.

Komarraju, Karau\& Schmeck(2009) concluded that extraversion was positively related with extrinsic motivation, suggesting that students with strong social needs may pursue a college degree as a means to an end.

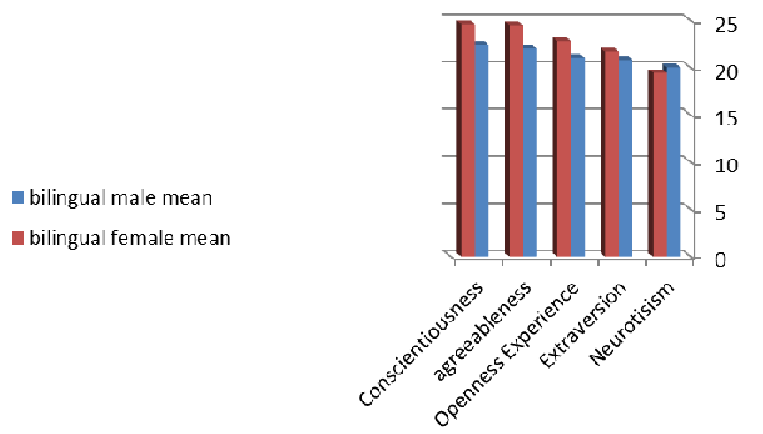

Figure 1. Discriptive statistics of big five personality traits on male and female bilingual learners

\section{Conclusion}

In conclusion, this study extends our understanding of the important role of personality traits in male and female bilingual learners. So, according to findings in this study, there wasn't significant difference between two groups of bilingual learners in big five personality traits .On the other hand, female bilinguals were more extrovert than male bilinguals.

In one study by Komarraju, Steven, Ronald, Schmeck\& Avdic(2011), they concluded that(a) openness was positively related with the two reflective learning styles (synthesis-analysis and elaborative processing), (b) neuroticism was negatively related with all the four learning styles, and (c) agreeableness and conscientiousness were positively related to all the four learning styles. Finally, extraversion was positively related with fact retention and elaborative processing. It is interesting that three personality traits (openness, agreeableness, and

conscientiousness) and all the four learning styles were positively correlated with GPA.

Future research could extend these findings by including other individual difference variables and on monolingual learners, too.

\section{Appendix A}

\section{Background Questionnaire}

\begin{tabular}{|c|c|c|}
\hline NO. & Question & Answer \\
\hline 1. & $\begin{array}{l}\text { Name: } \\
\text { نام }\end{array}$ & \\
\hline 2. & $\begin{array}{l}\text { Age } \\
\text { سن }\end{array}$ & \\
\hline 3. & $\begin{array}{l}\text { Gender: } \\
\text { جنيث }\end{array}$ & Male(مذكر) Female(مونث) \\
\hline 4. & نام مدرسه:Name of school & \\
\hline 5. & $\begin{array}{l}\text { Language or languages } \\
\text { which are used at } \\
\text { home(home language) } \\
\text { زبان يا زبانهايى دره دراده مينهد. }\end{array}$ & 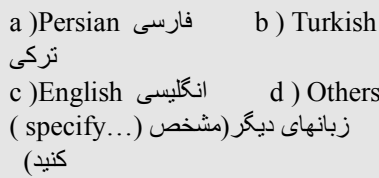 \\
\hline
\end{tabular}




\section{Appendix B}

Full name:

Gender:

Part I: English Grammar Select the Best Answer

1. Juan in the library this morning.

$\mathbb{C}$ A. is study $\mathbb{C}$ B. studying C. is studying

C D. are studying

2. Alicia, the windows please. It's too hot in here.

$\mathbb{C}$ A. opens $\mathbb{G}$ B. open $\mathbb{C}$ C. opened $\mathbb{C}$ D. will opened

3. The movie was the book.

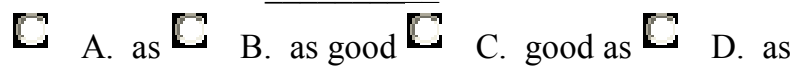
good as

4. Eli's hobbies include jogging, swimming, and

$\bar{\square}$ A. to climb mountains $\mathbb{C}$ B. climb mountains

$\square$ C. to climb $\square$ D. climbing mountains

5. Mr. Hawkins requests that someone by fax immediately.

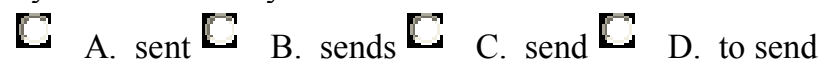
6. Who is , Marina or Sachiko?

$\mathbb{E}$ A. tallest $\mathbb{G}$ B. tall $\mathbb{C}$ C. taller $\mathbb{C}$ D. the tallest

7. The concert will begin fifteen minutes.

$\mathbb{C}$ A. in $\boldsymbol{C}$ B. on $\boldsymbol{C}$ C. with $\boldsymbol{C}$ D. about

8. I have only a Christmas cards left to write.

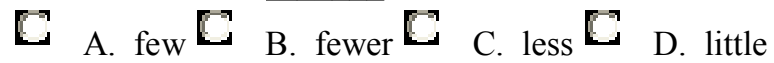

9. Each of the Olympic athletes even years.

$\mathbb{C}$ A. have been training $\mathbb{C}$ B. were

training $\quad$ C. has been training $\quad$ D. been training 10. Maria never late for work.

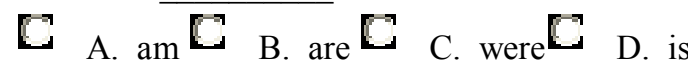

11. The company will upgrade computer information systems next month.

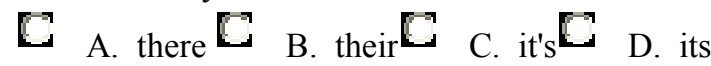
12. Cheryl likes apples, she does not like oranges.

$\square$ A. so $\square$ B. for $\square$ C. but $\mathbb{C}$ D. or 13. You were the New York office before 2 p.m.

$[$ A. suppose call $\square$ B. supposed to call

$\square$ C. supposed calling $\left[\begin{array}{c}\text { D. supposed call } \\ \square\end{array}\right.$

14. When I graduate from college next June, I a student here for five years.
$\mathbb{C}$ A. will have been $\mathbb{C}$ B. have been $\mathbb{C}$ C. has been $\mathrm{C}$. will have

15. Ms. Guth rather not invest that money in the stock market.
A. has to $\mathbb{C}$
B. could
C. would
D. must

\section{Part II: English Grammar Select the One Underlined Word or Phrase that is Incorrect}

16. The majority to the news is about violence or scandal.

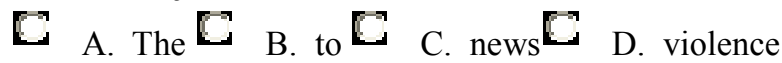

17. Takeshi swimmed one hundred laps in the pool yesterday.
C A. swimmed $\mathbb{C}$
B. hundred
C. in
CD. yesterday

18. When our vacation, we plan to spend three days scuba diving.

$\boldsymbol{E}$ A. When $\mathbb{C}$ B. plan $\mathbb{C}$ C. days $\mathbb{C}$ D. diving 19. Mr. Feinauer does not take critical of his work very well.

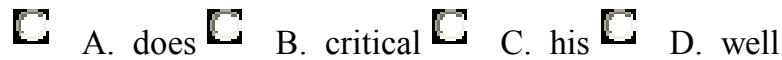
20. Yvette and Rinaldo send e-mail messages to other often.

$\square$ A. and $\square$ B. send $\square$ C. other $\square$ D. often 21. Mr. Olsen is telephoning a American Red Cross for help.

$\mathbb{C}$ A. is $\boldsymbol{C}$ B. a $\mathbb{C}$ C. Red $\boldsymbol{C}$ D. for

22. I had a enjoyable time at the party last night.

$\mathbb{C}$ A. a $\mathbb{C}$ B. time $\mathbb{C}$ C. at $\boldsymbol{C}$ D. last

23. The doctor him visited the patient's parents.

$\mathbb{C}$ A. The $\mathbb{C}$ B. him $\mathbb{C}$ C. visited $\mathbb{C}$ D. patient's 24. Petra intends to starting her own software business in a few years.

$\mathbb{C}$ A. intends $\mathbb{C}$ B. starting $\mathbb{C}$ C. software

D. few

25. Each day after school, Jerome run five miles.

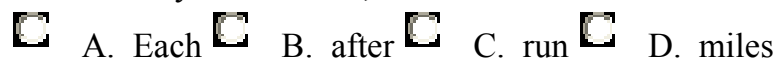
26. He goes never to the company softball games.

$\boldsymbol{E}$ A. never $\boldsymbol{E}$ B. the $\boldsymbol{E}$ C. softball $\boldsymbol{C}$ D. games 27. Do you know the student who books were stolen?

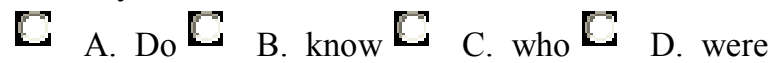
28. Jean-Pierre will spend his vacation either in Singapore nor the Bahamas.

C A. will $\mathbb{C}$ B. his $\mathbb{C}$ C. nor $\mathbb{D}$ D. Bahamas 29. I told the salesman that I was not interesting in buying the latest model.

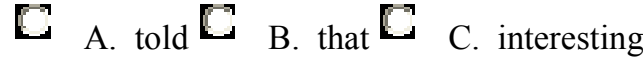

E D. buying

30. Frederick used work for a multinational corporation 
when he lived in Malaysia.

$\begin{array}{llll}\mathbb{C} & \text { A. used work } & & \text { B. multinational } \\ \mathbb{C} & \text { D. lived in } & \text { C. when }\end{array}$

\section{Part III. English Vocabulary Select the Best Answer}

31. The rate of has been fluctuating wildly this week.
C
A. money
B. bills
C. coins
C D. exchange

32. The bus arrives late during bad weather.
C A. every week
B. later
C. yesterday
D D. always

33. Do you where the nearest grocery store is?
C A. know
B. no
C. now
D. not

34. Jerry Seinfeld, the popular American comedian, has his audiences

$\mathbb{E}$ A. putting too many irons in the fire $\bar{B}$ B. keeping their noses out of someone's business

$\mathbb{C}$ C. rolling in the aisles $\mathbb{D}$. going to bat for someone

35. The chairperson will members to the subcommittee.
E A. appoint
B. disappoint
C. appointment
C
D. disappointed

36. The critics had to admit that the ballet was superb.
$\square$ A. procrastinate
C C. pathology
B. performance
D. psychosomatic

37. Peter says he can't

dinner tonight.
$[$ A. angel
B. across
C. accept
CD. almost

38. We were magical country. our invitation to

$\mathbb{E}$ A. upon $\mathbb{E}$ B. among $\mathbb{C}$ C. toward $\mathbb{C}$ D. in addition to

39. The hurricane caused damage to the city.
C A. extend $\mathbb{C}$
B. extended
C. extensive
B
D. extension

40. Many cultures have special ceremonies to celebrate a person's of passage into adulthood.
a
A. right
B. rite $\mathbb{C}$
C. writ
D. write

\section{Part IV. English Reading Comprehension Select the Best Answer}

\section{Directions to Erik's house}

Leave Interstate 25 at exit $7 \mathrm{~S}$. Follow that road (Elm Street) for two miles. After one mile, you will pass a small shopping center on your left. At the next set of traffic lights, turn right onto Maple Drive. Erik's house is the third house on your left. It's number 33, and it's white with green trim.

41. What is Erik's address?

$\left[\begin{array}{lll}\text { A. Interstate } 25 & \text { B. } 2 \text { Elm Street } & \text { C. } 13\end{array}\right.$

Erika Street $D$ D. 33 Maple Drive

42. Which is closest to Erik's house?

$\square$ A. the traffic lights $\square$ B. the shopping center

C C. exit 7S $\mathbb{C}$ D. a greenhouse

Date: May 16, 1998

To: Megan Fallerman

From: Steven Roberts

Subject: Staff Meeting

Please be prepared to give your presentation on the monthly sales figures at our upcoming staff meeting. In addition to the accurate accounting of expenditures for the monthly sales, be ready to discuss possible reasons for fluctuations as well as possible trends in future customer spending. Thank you.

43. The main focus of the presentation will be

E A. monthly expenditures $\mathbb{C}$ B. monthly salary figures $\mathbb{C}$ C. monthly sales figures

C D. staffmeeting presentations

44. Who will give the presentation?

$C$ A. the company president $[$ B. Megan Fallerman

C C. Steven Roberts $D$ D. future customers

The B\&B Tour

Spend ten romantic days enjoying the lush countryside of southern England. The counties of Devon, Dorset, Hampshire, and Essex invite you to enjoy their castles and coastline, their charming bed and breakfast inns, their museums and their cathedrals. Spend lazy days watching the clouds drift by or spend active days hiking the glorious hills. These fields were home to Thomas Hardy, and the ports launched ships that shaped world history. Bed and breakfasts abound, ranging from quiet farmhouses to lofty castles. Our tour begins August 15. Call or fax us today for more information 1-800-222-XXXX. Enrollment is limited, so please call soon.

45. Which of the following counties is not included in the tour?

$\mathbb{C}$ A. Devon $\mathbb{C}$ B. Cornwall $\mathbb{C}$ C. Essex

C. D. Hampshire

46. How many people can go on this tour? 

A. 10
B. an unlimited number
C. $2-8$
C
D. a limited number

47. What can we infer about this area of southern England?

$C$ A. The region has lots of vegetation. $D$

B. The coast often has harsh weather.

C. The sun is hot and the air is dry. $\mathrm{D}$. The land is flat.

Anna Szewcyzk, perhaps the most popular broadcaster in the news media today, won the 1998 Broadcasting Award. She got her start in journalism as an editor at the Hollsville County Times in Missouri. When the newspaper went out of business, a colleague persuaded her to enter the field of broadcasting. She moved to Oregon to begin a master's degree in broadcast journalism at Atlas University. Following graduation, she was able to begin her career as a local newscaster with WPSU-TV in Seattle, Washington, and rapidly advanced to national television. Noted for her quick wit and trenchant commentary, her name has since become synonymous with Good Day, America! Accepting the award at the National Convention of Broadcast Journalism held in Chicago, Ms. Szewcyzk remarked, "I am so honored by this award that I'm at a total loss for words!" Who would ever have believed it?

48. What is the purpose of this announcement?

C A. to invite people to the National Convention of

Broadcast Journalism $\mathrm{B}$. to encourage college students to study broadcasting $\mathrm{C}$. to recognize Ms. Szewcyzk's accomplishments $[$ D. to advertise a job opening at the Hollsville County Times

49. The expression "to become synonymous with" means

C A. to be the same as. $\mathrm{C}$. to be the opposite

of. $C$. to be in sympathy with. $C$ D. to be discharged from.

50. What was Ms. Szewczyk's first job in journalism?

C A. She was a T.V. announcer in

Washington. $\mathrm{B}$. She was a newscaster in

Oregon. $\mathrm{C}$. She was an editor for a newspaper in

Missouri. D. She was a talk show host in Chicago.

\section{Appendix C}

\section{Big Five Personality Traits Questionnaire}

Name:

Gender:

Age:

Grade:

High school

Number of language you use:

Strongly agree:5 Agree:4 neutral:3 Disagree:2

Strongly agree: 1

\begin{tabular}{|c|c|c|c|c|c|c|}
\hline Rating & Item & 1 & 2 & 3 & 4 & 5 \\
\hline 1 & I am the life of the party/ & & & & & \\
\hline 2 & I feel little concern for others/ & & & & & \\
\hline 3 & I am always prepared/ & & & & & \\
\hline 4 & I get stressed out easily/ & & & & & \\
\hline 5 & I have a rich vocabulary/ & & & & & \\
\hline 6 & I don't talk a lot/. & & & & & \\
\hline 7 & I am interested in people/ & & & & & \\
\hline 8 & I Leave my belongings around/ & & & & & \\
\hline 9 & I am relaxed most of the time/ & & & & & \\
\hline 10 & $\begin{array}{l}\text { I have difficulty understanding } \\
\text { abstract ideas/ }\end{array}$ & & & & & \\
\hline 11 & I feel comfortable around people/ & & & & & \\
\hline 12 & I insult people/ & & & & & \\
\hline 13 & I pay attention to details/ & & & & & \\
\hline 14 & I worry about things/ & & & & & \\
\hline 15 & I have a vivid imagination/ & & & & & \\
\hline 16 & I keep in the background/ & & & & & \\
\hline 17 & I sympathize with others' feelings/ & & & & & \\
\hline 18 & I make a mess of things/ & & & & & \\
\hline 19 & I seldom feel blue/ & & & & & \\
\hline 20 & $\begin{array}{l}\text { I am not interested in abstract } \\
\text { ideas/ }\end{array}$ & & & & & \\
\hline 21 & I start conversations/ & & & & & \\
\hline 22 & $\begin{array}{l}\text { I am not interested in other } \\
\text { people's problems/ }\end{array}$ & & & & & \\
\hline 23 & I get chores done right away/ & & & & & \\
\hline 24 & I am easily disturbed/ & & & & & \\
\hline 25 & I have excellent ideas/ & & & & & \\
\hline 26 & I have little to say/ & & & & & \\
\hline 27 & I have a soft heart/ & & & & & \\
\hline 28 & $\begin{array}{l}\text { I often forget to put things back in } \\
\text { their proper place/ }\end{array}$ & & & & & \\
\hline 29 & I get upset easily/ & & & & & \\
\hline 30 & I do not have a good imagination/ & & & & & \\
\hline 31 & $\begin{array}{l}\text { I talk to a lot of different people at } \\
\text { parties/ }\end{array}$ & & & & & \\
\hline 32 & $\begin{array}{l}\text { I am not really interested in } \\
\text { others/ }\end{array}$ & & & & & \\
\hline 33 & I like order/ & & & & & \\
\hline 34 & I change my mood a lot/ & & & & & \\
\hline 35 & I am quick to understand things/ & & & & & \\
\hline 36 & $\begin{array}{l}\text { I don't like to draw attention to } \\
\text { myself/ }\end{array}$ & & & & & \\
\hline 37 & I take time out for others/ & & & & & \\
\hline 38 & I shirk my duties/ & & & & & \\
\hline 39 & I have frequent mood swings/ & & & & & \\
\hline 40 & I use difficult words/ & & & & & \\
\hline 41 & $\begin{array}{l}\text { I don't mind being the center of } \\
\text { attention/ }\end{array}$ & & & & & \\
\hline 42 & I feel others' emotions/ & & & & & \\
\hline 43 & I follow a schedule/ & & & & & \\
\hline 44 & I get irritated easily/ & & & & & \\
\hline 45 & I spend time reflecting on things/ & & & & & \\
\hline 46 & I am quiet around strangers/ & & & & & \\
\hline 47 & I make people feel at ease/ & & & & & \\
\hline 48 & I am exacting in my work/ & & & & & \\
\hline 49 & I often feel blue/ & & & & & \\
\hline 50 & I am full of ideas/ & & & & & \\
\hline
\end{tabular}




\section{References}

[1] Cherry,K.(2013). The Big Five Personality Dimensions. Overview of the Big Five Personality Dimensions. C2013 About.com.

[2] Costa, P. T., \& McCrae, R. R. (1992). NEO PI-R: Professional Manual: Revised NEO PI-R and NEO-FFI. Florida: Psychological Assessment Resources, Inc.

[3] Fiske, D.W. (1949). Consistency of the factorial structures of personality ratings from different sources. Journal of Abnormal Social Psychology, 44, 329-344.

[4] Goldberg, L. R. (1981) Language and individual differences: The search for universals in personality lexicons. In L. Wheeler (Ed.), Review of Personality and Social Psychology, Vol. 2. Beverly Hills, CA: Sage.

[5] Gosling,S, Rentfrow,P, and Swann,W. (2003).A very brief measure of the Big-Five. Journal of Research in Personality 37 (2003) 504-528.personality domains

[6] Karbalaei,A.(2010). A Comparison of the Metacognitive Reading Strategies Used by EFL and ESL Readers. The Reading Matrix (C) 2010, Volume 10, Number 2.
[7] Komarraju ,M,Karau,S , Schmeck,R \&Avdic,A(2011). The Big Five personality traits, learning styles, and academic achievement. Personality and Individual Differences 51 (2011) 472-477.

[8] Komarraju ,M,Karau,S \& Schmeck,R.(2009). Role of the Big Five personality traits in predicting college students' academic motivation and achievement. Learning and Individual Differences 19 (2009) 47-52.

[9] Maghsoudi,M.(2010). The interaction between bilingualism, educational and social factors and foreign language learning in Iran. Journal of Language.

[10] McCrae, R.R., \& Costa, P.T. (1987) Validation of the fivefactor model of personality across instruments and observers. Journal of Personality and Social Psychology, 52, 81-90.

[11] Norman, W.T. (1963). Toward an adequate taxonomy of personality attributes: Replicated factor structure in peer nomination personality ratings. Journal of Abnormal and Social Psychology, 66, 574-583.

[12] Poropat, A. E. (2009). A meta-analysis of the five-factor model of personality and

[13] academic performance. Psychological Bulletin, 135, 322338 